К.В. Войцеховська, Л.Г. Воронков

Державна установа «Національний науковий центр «Інститут кардіології імені академіка М.Д. Стражеска» НАМН України», Київ

\title{
Прогностичне значення втрати маси тіла та показників антропометрії у пацієнтів із хронічною серцевою недостатністю та зниженою фракцією викиду лівого
}

\section{шлуночка}

Мета - вивчення прогностичної цінності втрати маси тіла й антропометричних показників у пацієнтів із хронічною серцевою недостатністю (ХСН) зі зниженою фракцією викиду лівого шлуночка (ФВ ЛШ). Об'єкт і методи дослідження. Обстежено 120 пацієнтів із XCH II-IV функціонального класу за NYHA з ФВ ЛШ \$35\%. Пацієнтам проводили загальноклінічне та фізикальне обстеження, розрахунок частки жирової маси тіла, вимірювання товщини шкірно-жирової складки (ТШЖС) в чотирьох точках за допомогою каліпометра, окружностей плеча ненапруженої та напруженої руки, талії та стегна. Результати. Пацієнти із втратою маси тіла $\geqslant 6 \%$ за останні 6 міс мали достовірно гірший прогноз щодо виживаності та настання комбінованої критичної події (ККП). Частота летального кінця вища у пацієнтів з нижчими індексом маси тіла та окружністю талії. Пацієнти з меншими окружністю плеча та стегна, ТШЖС над біцепсом та під лопаткою мали достовірно гірший прогноз щодо виживаності та настання ККП. Висновки. Серед пацієнтів із ХСН зі зниженою ФВ ЛШ втрата маси тіла श6\% за останні 6 міс асоційована з гіршою виживаністю та частішою госпіталізацією. Показники індексу маси тіла, окружності талії продемонстрували низьку прогностичну значимість щодо настання ККП, однак достатню інформативність щодо виживаності. ТШЖС над трицепсом та в паховій ділянці, частка жирової маси тіла не показали достатньої інформативності щодо прогнозу довгострокової виживаності цієї категорії пацієнтів. 3 гіршим прогнозом, як виживаність, так і настання ККП, асоціюються менша окружність плеча, стегна, ТШЖС над біцепсом та під лопаткою.

Ключові слова: хронічна серцева недостатність, прогноз, антропометрія.

\section{Вступ}

На сьогодні хронічна серцева недостатність $(\mathrm{XCH})$ - одна з найважливіших проблем сучасної кардіології, що багато в чому пояснюється ї̈ поганим клінічним прогнозом (Воронков Л.Г., 2012). Смертність від ХСН в перші 5 років після встановлення діагнозудосягає $59 \%$ серед чоловіків і 45\% - серед жінок (Ambrosy A.P. et al., 2014). Один із 4-5 пацієнтів помирає протягом 1-го року після встановлення діагнозу (McMurray J.J., Stewart S., 2000). Особливу когорту в структурі смертності від ХСН становлять пацієнти із прогресуючою втратою маси тіла (ВМТ). ВМТ приХСН пов'язана здостовірно вищим ризиком госпіталізацій та смертності хворих, незалежно від віку, фракції викиду лівого шлуночка (ФВ ЛШ) або функціонального класу (ФК) серцевої недостатності (Anker S.D. etal., 2003). Поширеність синдрому кахексії становить 13,3-16\%, смертність пацієнтів за 18 міс спостереження - 50\% (von Haehling S., Anker S.D., 2010). Європейське товариство кардіологів (European Society of Cardiology - ESC) як критерій кахексії пропонує показник ВМТ $\geqslant 6 \%$ за попередні 6-12 міс (Ponikowski P. et al., 2016). Водночас нерідко відсутня можливість отримання достовірної інформації щодо динаміки маси тіла за такий період. Актуальним вбачається виділення маркерів стану пацієнта, які надали б альтернативну інформацію щодо прогнозу.

Мета - вивчення прогностичної цінності антропометричних показників у пацієнтів із ХCH зі зниженою ФВ ЛШ.

\section{Об'єкт і методи дослідження}

На базі відділу серцевої недостатності ДУ «Національний науковий центр «Інститут кардіології імені академіка М.Д. Стражеска» НАМН України» в період 2014-2019 рр. обстежено 120 гемодинамічно стабільних пацієнтів із ХCH (97 чоловіків, 23 жінки) віком 18-75 років (середній вік-60,95 0,86 року) II-IV ФК за NYHA з ФВ лШ $\leqslant 35 \%$ (середня величина $-26,76 \% \pm 0,59$ ). Етіологічним фактором розвитку XCH були ішемічна хвороба серця ( $n=104)$ або дилатаційна кардіо-

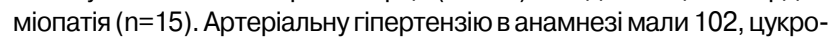

вий діабет - 34 пацієнти. Постійну або персистуючу форму фібриляції передсердь в анамнезі мали більше половини - 69 (57,5\%), інфаркт міокарда - 49 (40,8\%) пацієнтів.

Удослідження не включали пацієнтів віком $>75$ років, з навмисною BMT, набутими івродженими вадами серця, захворюваннями шлунково-кишкового тракту в стадії загострення, які обмежують можливість прийому їжі або характеризуються синдромом мальабсорбції, гіпо- та гіпертиреозом, інфарктом міокарда, мозковим інсультом або тромбоемболією гілок легеневої артерії давністю <3 міс, запальними та рестриктивними ураженнями серця, інсулінозалежним цукровим діабетом, хронічним легеневим серцем, хронічною нирковою недостатністю V стадії, термінальною стадією печінкової недостатності, бронхіальною астмою або хронічним обструктивним захворюванням легень III-IV стадії, онкологічними та інфекційними захворюваннями.

Діагноз основного захворювання визначали на підставі загальноклінічного обстеження, спеціальнихінструментальнихі лабораторних методів. ХCH діагностували згідно з рекомендаціями ESC з діагностики та лікування XCH та відповідними рекомендаціями Асоціації кардіологів України (Ponikowski P. etal., 2016; Воронков Л.Г. та співавт., 2017). Пацієнтів включали в дослідження у фазу клінічної компенсації. Протокол дослідження схвалений етичним комітетом ДУ «Національний науковий центр «Інститут кардіології імені академіка М.Д. Стражеска» НАМН України». В усіх учасників отримано письмову інформовану згоду на участь у дослідженні.

Усім пацієнтам проводили загальноклінічне фізикальне обстеження, вимірювання товщини шкірно-жирової складки (ТШЖС) в чотирьох точках за допомогою каліпометра, розрахунок частки жирової маси тіла (ЧЖМТ) з використанням формули Durnin -Womersley (Deurenberg P. et al., 1991), вимірювання окружностей плеча ненапруженої та напруженої руки, талії та стегна. Критерієм розподілу пацієнтів за групами слугувала ВМТ за останні 6 міс $\geqslant 6 \%$ згідно з рекомендаціями ESC з діагностики та лікування XCH (Ponikowski P. etal., 2016). У дослідження включали пацієнтів, які мали чіткі анамнес- 
тичні відомості щодо динаміки маси тіла за зазначений період або дані медичної документації. Максимальний період спостереження становив 48 міс.

Лікування здійснювали згідно з чинними стандартами ESC та Української асоціації кардіологів (Ponikowski P. et al., 2016; Воронков Л.Г. та співавт., 2017), що включало призначення діуретиків, блокаторів $\beta$-адренорецепторів, інгібіторів ангіотензинперетворювального ферменту або сартанів, антагоністів мінералокортикоїдних рецепторів.

Стан хворих оцінювали методом опитування по телефону.

Статистичну обробкуінформації здійснювали задопомогою програми «Microsoft Excel» («IBM SPSS Statistics», версія 23.0). Застосовували такі методи описової статистики, як точний критерій Фішера, гіпотезу про вірогідність різниці значень показників у групах перевіряли за допомогою непараметричного критерію Манна - Уїтні. При нормальному розподілі даних визначали середні значення та середні відхилення, при ненормальному - медіану, нижній та верхній квартилі. Для виявлення та оцінки зв'язків між параметрами користувалися коефіцієнтом рангової кореляції Спірмена. Для оцінки та порівняння двох кривих виживаності, госпіталізації та настання комбінованої критичноїподії (ККП) використовували логарифмічний ранговий критерій з побудовою кривих Каплана - Мейєра.

\section{Результати та їх обговорення}

Пацієнти розподілені на дві групи залежно від ВМТ за останні 6 міс: 1 -ша $-\geqslant 6 \%, 2-г а-<6 \%$. У $59(49,2 \%)$ пацієнтів виявлено кахектичний стан. На І етапі групи пацієнтів були зіставні за віком, ФК за NYHA, ФВ ЛШ, а також структурою фармакотерапії. Пацієнти обох груп не відрізнялися за такими гемодинамічними показниками, як частота серцевих скорочень (ЧСС), систолічний артеріальний тиск (САТ), ФВ ЛШ, та за структурою призначеного лікування. Водночас пацієнти з ВМТ $\geqslant 6 \%$ були старшими іхарактеризувалися більшою часткою осіб із XCH III-IV ФК за NYHA (таблиця).

Таблиця. Порівнянність груп пацієнтів за віком, гендерною ознакою, ФК, ЧСС, САТ, ФВ ЛШ, структурою лікування

\begin{tabular}{|c|c|c|c|}
\hline \multirow{2}{*}{ Показник } & \multicolumn{2}{|c|}{ Пацієнти з ВМТ } & \multirow[b]{2}{*}{ p } \\
\hline & $\geqslant 6 \%(n=59)$ & $<6 \%(n=61)$ & \\
\hline Вік, років & $64(58-69)$ & $57(51,5-68,0)$ & 0,029 \\
\hline Чоловіки, n=97 (80,8\%) & $50(84,7)$ & $47(77,0)$ & 0,284 \\
\hline \| ФК за NYHA, n=46 (38,3\%) & $4(6,8)$ & $42(68,9)$ & $<0,001$ \\
\hline III-IV ФК за NYHA, $n=74(61,7 \%)$ & $55(93,2)$ & $19(31,1)$ & $<0,001$ \\
\hline ЧСС, уд./хв & $76(70-90)$ & $80(72-90)$ & 0,339 \\
\hline САТ, мм рт. ст. & $115(105-120)$ & $120(110-120)$ & 0,634 \\
\hline ФВ ЛШ, \% & $26,0(21,0-32,0)$ & $28,0(23,5-33,0)$ & 0,190 \\
\hline $\begin{array}{l}\text { Блокатори } \beta \text {-адренорецепторів, } \mathrm{n}=115 \\
(95,8 \%)\end{array}$ & $56(94,9)$ & $59(96,7)$ & 0,621 \\
\hline $\begin{array}{l}\text { Інгібітори ангіотензинперетворюваль- } \\
\text { ного ферменту/сартани, n=83 (69,2\%) }\end{array}$ & $40(67,8)$ & $43(70,5)$ & 0,749 \\
\hline $\begin{array}{l}\text { Антагоністи мінералокортикоїдних } \\
\text { рецепторів, } n=112(93,3 \%)\end{array}$ & $57(96,6)$ & $55(90,2)$ & 0,157 \\
\hline
\end{tabular}

Проведено порівняння та аналіз кривих виживаності пацієнтів залежно від ВМТ. Встановлено, що група пацієнтів із ВМТ $\geqslant 6 \%$ мала достовірно гірший прогноз щодо виживаності та настання ККП (смерть або госпіталізація) на відміну від іншої групи (рис. 1, 2). Після вирівнювання груп за віком ця різниця зберігалася.

Вивчення прогностичної інформативності кожногоз антропометричних показників проводили, порівнюючи відповідні актуарні криві у двох групах, що сформовані за принципом «значення показника більше або менше медіани для всієї групи $(n=120)$ ».

На наступному етапі намагалися визначити зв'язок індексу маси тіла (IMT) із клінічним прогнозом пацієнтів із ХCH. 3 цією метою розділили досліджуваних на дві групи відповідно до медіани IMT: $\geqslant 27,8$ та $<27,8 \mathrm{kr} / \mathrm{M}^{2}$. Зазначимо, що у пацієнтів із ВМT $\geqslant 6 \%$ медіана IMT

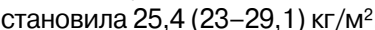

IMT суттєво не вплинув на настання ККП (рис. 3 , 4), в той час як частота летального кінця була значно вищою угрупі пацієнтів з нижчими показниками IMT. При розподілі груп залежно від значення медіани окружності талії (Ме 107 см) спостерігали достовірно вищий ризик летального кінця у групі з ї̈ нижчими показниками ( $(\mathrm{=}=0,015)$, однаквірогідність настання ККПдостовірно не відрізнялася $(\mathrm{p}=0,057)$.

Пацієнти з меншими значеннями окружності плеча мали достовірно гірший прогноз щодо виживаності та настання ККП (рис. 5-6). Ще більшу різницю відносно досягнення прогностичних точок демонструє показник окружності стегна. Нижчі показники

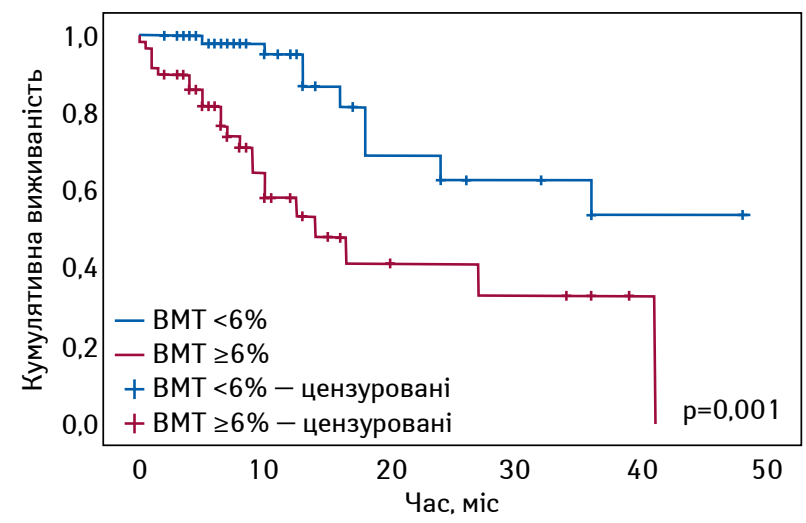

Рис. 1. Криві виживаності пацієнтів із ХСН з ФВ лШ $\leqslant 35 \%$ залежно від ВМТ

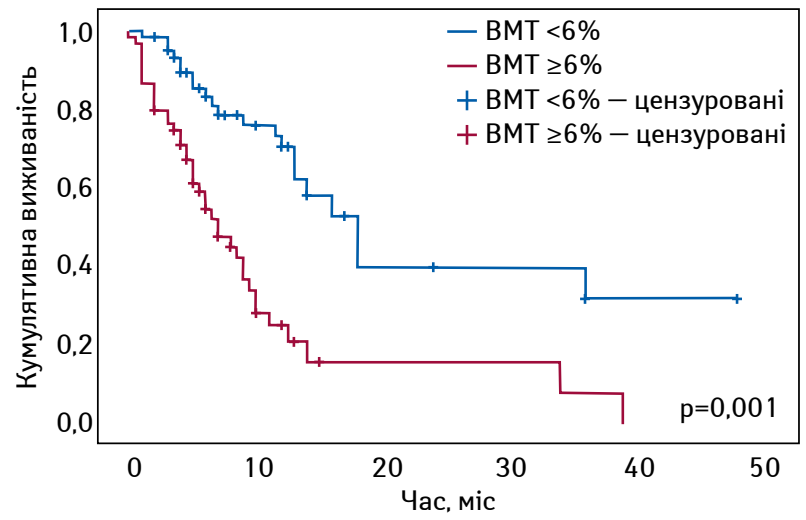

Рис. 2. Криві настання ККП (смерть або госпіталізація) залежно від ВМТ

ТШЖС над біцепсом достовірно асоційовані з гіршим прогнозом як виживаності, так і настання ККП (рис. 7, 8). Також при розподілі груп за медіаною ТШЖС під лопаткою (Ме 21,0 мм) відзначали вищий ризик смерті $(p=0,020)$ та настання ККП $(p=0,037)$. Водночас показник ТШЖС в паховій ділянці не впливав на прогноз щодо виживаності та настання ККП.

При розподілі пацієнтів за медіаною ЧЖМТ (Ме 28,8\%) та ТШЖС над трицепсом (Ме 11,5 cм) виявлено, що менші їх значення впливають на ризик настання ККП ( $p=0,020$ та $p=0,005$ відповідно), однак прогноз виживаності достовірно не відрізнявся ( $p=0,092$ та $p=0,166$ відповідно).

Проведене дослідження підтвердило широку розповсюдженість феномену ВМТ (майже 50\%) серед пацієнтів із ХСН та ФВ ЛШ $\leqslant 35 \%$, а також значну прогностичну значимість кахектичного процесу у цій категорії пацієнтів (Springer J. et al., 2006), що асоціюється, як з гіршою виживаністю, так і вищими показниками госпіталізації. Однак, враховуючи труднощі, які можуть виникнути у практичних лікарів стосовно оцінки динаміки маси тіла у пацієнтів із ХCH, ми намагалися визначити цінність антропометричних показників у стратифікації ризику фатальних подій у цієї категорії пацієнтів. Встановлено, що нижчі показники окружності плеча та стегна, які переважно відображають м'язову масу кінцівок, у цих пацієнтів чітко асоційовані з гіршими прогнозом. Відомо, що клінічні наслідки втрати м'язової тканини суттєві; зменшення її маси пов'язане з підвищенням смертності, зниженням функціональної здатності, втратою працездатності, зниженням якості життя, збільшенням ризиків падінь у пацієнтів із XCH (Visser M. et al., 1998; Newman A.B. et al., 2003; Lee C.G. et al., 2011; Santanasto A.J. et al., 2017). Непрямим підтвердженням клінічної ролі вищезазначених прогностичних показників можуть слугувати попередньо отримані нами прямі достовірні кореляційні зв'язки окружності плеча з якістю життя пацієнтів та окружності стегна з функціональними показниками (дистанція з 6-хвилинною ходою, індекс фізичної активності).

Увага до вивчення ЧЖМТ у пацієнтів із ХСН посилена завдяки так званому парадоксу ожиріння. Численні дослідження демонструють підвищений ризик розвитку ХCH при ожирінні (Eaton C.B. et al., 2016; Ndumele C.E. et al., 2016), тоді як інші свідчать про те, що ожиріння привже розвинутій серцевій недостатностіможепокращуватипрогноз 


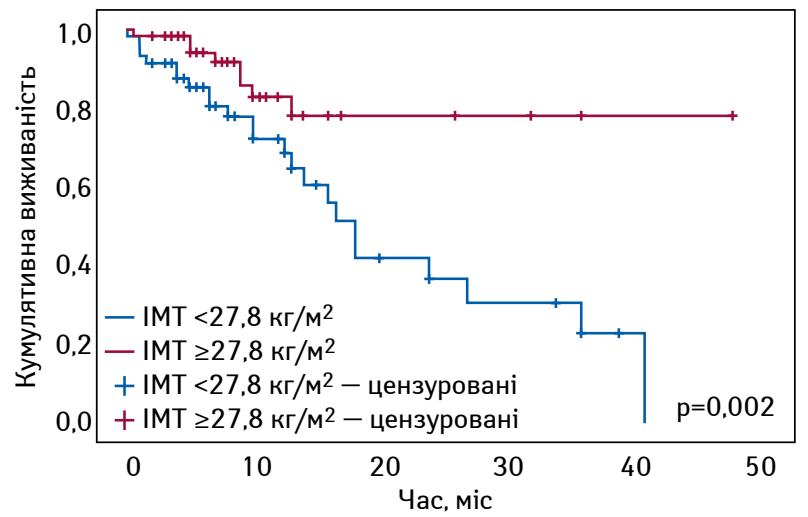

Рис. 3. Криві виживаності пацієнтів із ХСН з ФВ ЛШ $\leqslant 35 \%$ залежно від медіани IMT

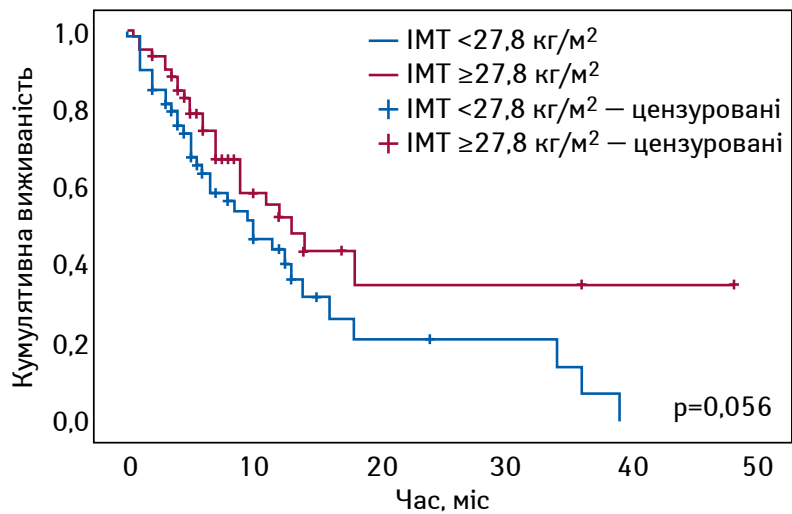

Рис. 4. Криві настання ККП (смерть або госпіталізація) залежно від медіани IMT

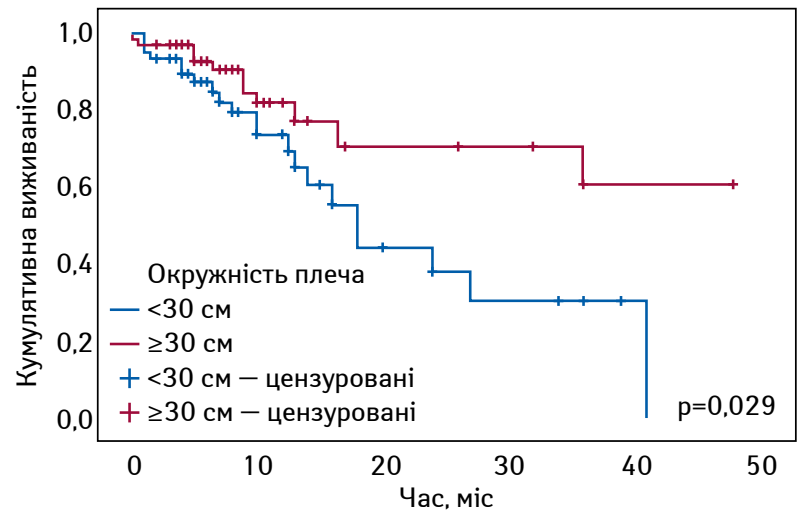

Рис. 5. Криві виживаності пацієнтів із ХСН з ФВ ЛШ $\leqslant 35 \%$ залежно від медіани окружності плеча

(Lavie C.J. et al., 2016; Oga E.A., Eseyin O.R., 2016). Більшість клінічних досліджень у рамках «парадоксу ожиріння» для оцінки складу тіла івизначення надмірної маси або ожиріння у пацієнтів використовують значення IMT. Цепояснюєтьсяповсюдним визнанням методуузв'язку з простотою його використання. Проте надійність IMT як показника ожиріння поставлена під сумнів. 3'являються дані про те, що при діагностиці ожиріння численні альтернативні методи, серед яких антропометричні показники, можуть бути точнішими. Так, увиконаній нами роботі виявлено зв'язок IMT з виживаністю, однак впливу IMT на настання ККП не відзначено. При вивченні показників ТШЖС, що найточніше відображають ЧЖМТ, нами встановлено, що більші показники ТШЖС над біцепсом та під лопаткою пов'язані з кращою виживаністю пацієнтів. Вивчення показників, що характеризують ТШЖС, продемонструвало, що прямі виміри ТШЖС над біцепсом та під лопаткою, навідмінувідрозрахункового показникаЧЖМТ, демонструють перевагу у прогнозуванні виживаності та досягнення ККП пацієнтів із ХСН та зниженою ФВ ЛШ.

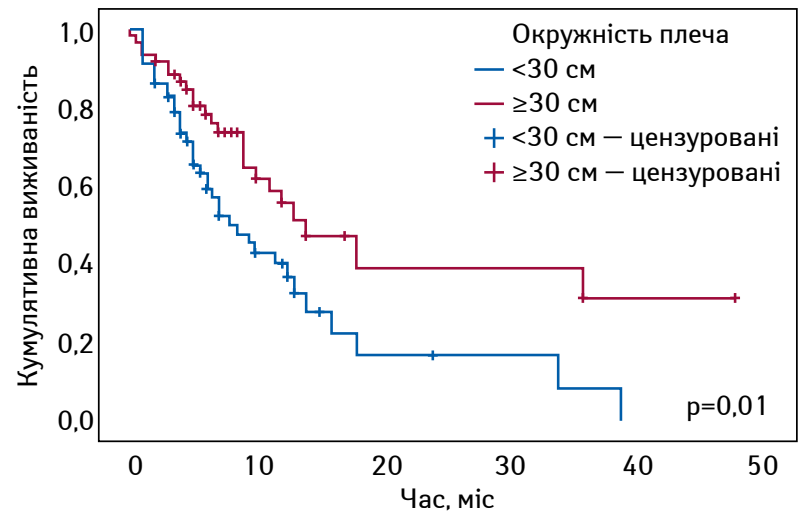

Рис. 6. Криві настання ККП (смерть або госпіталізація) залежно від медіани окружності плеча

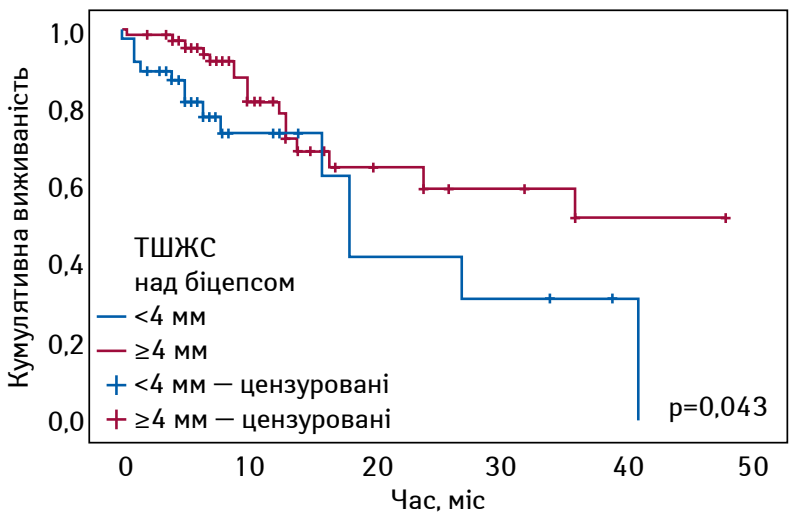

Рис. 7. Криві виживаності пацієнтів із ХСН з ФВ ЛШ $\leqslant 35 \%$ залежно від медіани ТШЖС над біцепсом

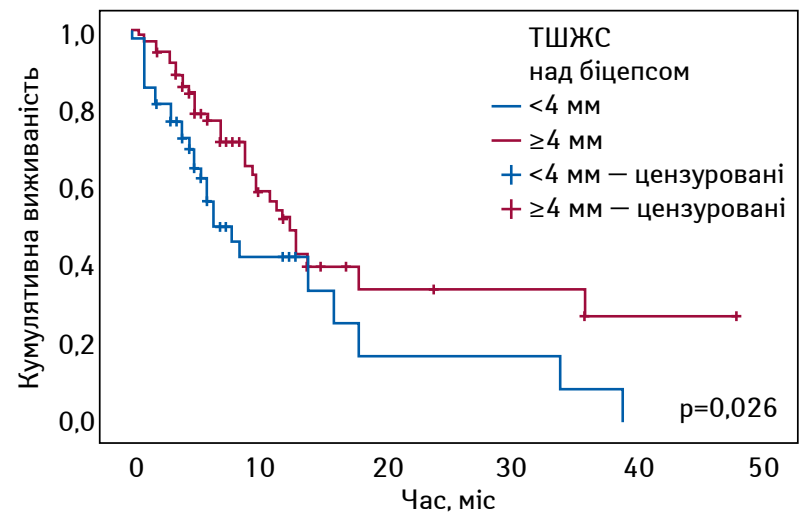

Рис. 8. Криві настання ККП (смерть або госпіталізація) залежно від медіани ТШЖС над біцепсом

На сьогодні у фахівців немає єдиної думки щодо механізму «парадоксу ожиріння» серед пацієнтів із ХСН. Існують лише теорії, що пояснюють це явище. ХСН за своєю суттю - катаболічний стан; досить часто такі пацієнти мають ознаки кахексії, яка, в свою чергу, асоціюється з несприятливим прогнозом і високим ризиком смерті. Нацьому тлі у «вигідному» становищі перебуваютьпацієнти зХСН та ознаками ожиріння, оскільки мають такий підвищений метаболічний резерв, як жирова тканина (Anker S.D. et al., 1997).

Виявлена нами статистично висока прогностична інформативність деяких антропометричних показників дозволяє рекомендувати проведення антропометричних вимірів в усіх пацієнтів із ХCH та зниженою ФВ ЛШ з метою стратифікації їх клінічного ризику.

\section{Висновки}

1. Середпацієнтів із ХСН та зниженою ФВ ЛШ ВМТ $\geqslant 6 \%$ за останні 6 міс відзначена у 49\% випадків та асоційована з гіршою виживаністю та вищою частотою госпіталізації пацієнтів. 
2. Показники IMT, окружності талії показали низьку прогностичну значимість щодо настання ККП, однак достатню інформативність щодо виживаності. Показники ТШЖС над трицепсом та в паховій ділянці, ЧЖМТ не показали достатньої інформативності щодо прогнозу довгострокової виживаності цієї категорії пацієнтів.

3. 3 гіршим прогнозом як виживаності, так і настання ККП асоціюються нижчі показники окружності плеча, стегна, ТШЖС над біцепсом та під лопаткою.

\section{Список використаної літератури}

Воронков Л.Г., Амосова К.М., Дзяк Г.В. та ін. (2017) Рекомендаціі Асоціації кардіологів України 3 діагностики та лікування хронічної серцевої недостатності (http://strazhesko.org.ua/upload/rekomendaciyi-hsn-a6-ost.pdf).

Воронков Л.Г. (2012) Пацієнт із ХCH в Україні: аналіз даних популяції пацієнтів, обстежених у рамках першого національного зрізового дослідження UNIVERS. Серцева недостатність, 2: 6-13.

Ambrosy A.P., Fonarow G.C., Butler J. et al. (2014) The global health and economic burden of hospitalizations for heart failure: lessons learned from hospitalized heart failure registries. J. Am. Coll. Cardiol., 63(12): 1123-1133.

Anker S.D., Negassa A., Coats A.J. et al. (2003) Prognostic importance of weight loss in chronic heart failure and the effect of treatment with angiotensinconverting-enzyme inhibitors: an observational study. Lancet, 361(9363): 10771083.

Anker S.D., Ponikowski P., Varney S. et al. (1997) Wasting as independent risk factor for mortality in chronic heart failure. Lancet, 349(9058): 1050-1053.

Deurenberg P., Weststrate J.A., Seidell J.C. (1991) Body mass index as a measure of body fatness: age- and sex-specific prediction formulas. Br. J. Nutr. 65(2): 105-114.

Eaton C.B., Pettinger M., Rossouw J. et al. (2016) Risk factors for incident hospitalized heart failure with preserved versus reduced ejection fraction in a multiracial cohort of postmenopausal women. Circ. Heart Fail., 9: e002883.

Lavie C.J., Sharma A., Alpert M.A. et al. (2016) Update on obesity and obesity paradox in heart failure. Prog. Cardiovasc. Dis., 58(4): 393-400.

Lee C.G., Boyko E.J., Nielson C.M. et al.; Osteoporotic Fractures in Men Study Group (2011) Mortality risk in older men associated with changes in weight, lean mass, and fat mass. J. Am. Geriatr. Soc., 59(2): 233-240.

McMurray J.J., Stewart S. (2000) Epidemiology, aetiology, and prognosis of heart failure. Heart, 83: 596-602.

Ndumele C.E., Matsushita K., Lazo M. et al. (2016) Obesity and subtypes of incident cardiovascular disease. J. Am. Heart Assoc., 5: e003921.

Newman A.B., Haggerty C.L., Goodpaster B. et al.; Health Aging And Body Composition Research Group (2003) Strength and muscle quality in a wellfunctioning cohort of older adults: the Health, Aging and Body Composition Study. J. Am. Geriatr. Soc., 51(3): 323-330.

Oga E.A., Eseyin O.R. (2016) The obesity paradox and heart failure: a systematic review of a decade of evidence. J. Obes., 2016: 9040248.

Ponikowski P., Voors A.A., Anker S.D. et al. (2016) ESC Guidelines for the diagnosis and treatment of acute and chronic heart failure: The Task Force for the diagnosis and treatment of acute and chronic heart failure of the European Society of Cardiology (ESC). Eur. Heart J., 37(27): 2129-2200.

Santanasto A.J., Goodpaster B.H., Kritchevsky S.B. et al. (2017) Body composition remodeling and mortality: the health aging and body composition study. J. Gerontol. Biol. Sci. Med. Sci., 72(4): 513-519.

Springer J., Filippatos G., Akashi Y.J., Anker S.D. (2006) Prognosis and therapy approaches of cardiac cachexia. Curr. Opin. Cardiol., 21(3): 229-233.

Visser M., Harris T.B., Langlois J. et al. (1998) Body fat and skeletal muscle mass in relation to physical disability in very old men and women of the Framingham Heart Study. J. Gerontol. Biol. Sci. Med. Sci., 53(3): M214-M221.

von Haehling S., Anker S.D. (2010) Cachexia as a major underestimated and unmet medical need: facts and numbers. J. Cachexia Sarcopenia Muscle, 1(1): $1-5$.

\section{Прогностическое значение потери массы тела и показателей антропометрии у пациентов с хронической сердечной недостаточностью и сниженной фракцией выброса левого желудочка \\ Е.В. Войцеховская, Л.Г. Воронков}

Резюме. Цель - изучение прогностической ценности потери массы тела и антропометрических показателей у пациентов с хрониче- ской сердечной недостаточностью (ХСH) и сниженной фракцией выброса левого желудочка (ФВ ЛЖ). Объект и методы исследования. Обследовано 120 пациентов с XCH II-IV функционального класса по NYHA с ФВ ЛЖ $\leqslant 35 \%$. Пациентам проводили общеклиническое и физикальное обследование, расчет доли жировой массы тела, измерение толщины кожно-жировой складки (ТКЖС) в четырех точках с помощью калипометра, окружностей плеча ненапряженной и напряженной руки, талии и бедра. Результаты. Пациенты с потерей массы тела $\geqslant 6 \%$ за последние 6 мес имели достоверно худший прогноз выживаемости и наступления комбинированного критического события (ККС). Частота смертельного исхода выше в группе пациентов с меньшими индексом массы тела и окружностью талии. Пациенты с более низкими значениями окружности плеча и бедра, ТКЖС над бицепсом и под лопаткой имели достоверно худший прогноз выживаемости и наступления ККП. Выводы. Среди пациентов с ХСН и сниженной ФВ ЛЖ потеря МT $\geqslant 6 \%$ за последние 6 мес ассоциировалась с худшей выживаемостью и более частой госпитализацией. Показатели индекса массы тела, окружности талии продемонстрировали низкую прогностическую значимость относительно наступления ККС, однако достаточную информативность относительно выживаемости. ТКЖС над трицепсом и в паховой области, доля жировой массы тела не показали достаточной информативности относительно прогноза долгосрочной выживаемости этой категории пациентов. С худшим прогнозом как выживаемости, так и наступления ККС ассоциируются более низкие показатели окружности плеча, бедра, ТКЖС над бицепсом и под лопаткой.

Ключевые слова: хроническая сердечная недостаточность, прогноз, антропометрия.

\section{The prognostic value of body weight loss and anthropometry indices in patients with chronic heart failure and decreased left ventricular ejection fraction}

\section{K.V. Voytsekhovskaya, L.G. Voronkov}

Summary. The aim - to study the prognostic significance of body weight loss and anthropometric parameters in patients with chronic heart failure (CHF) and reduced left ventricular ejection fraction ( LVEF). Materials and methods. 120 patients with CHF, II-IV NYHA class, with LV EF $\leqslant 35 \%$ were examined. Patients were subjected to a general clinical and physical examination, calculating the percentage of body fat, measuring the thickness of the skin-fat fold (TSFF) at 4 points using a calipometer, the circumference of the shoulder with a strained and tense arm, waist and hip. Results. Patients with weight loss (WL) $\geqslant 6 \%$ in the last 6 months had a significantly worse prognosis for the survival and occurrence of a combined critical event (CCE). The incidence of fatalities was higher in patients with lower body mass index and waist circumference. Patients with lower shoulder and hip circumferences, TSFF above the biceps, and under the shoulder blade had a significantly worse prognosis regarding the survival and onset of CCE. Conclusions. Among patients with CHF and reduced LVEF, WL $\geqslant 6 \%$ in the last 6 months is associated with poorer survival and more frequent hospitalization. Body mass index, waist circumference showed low prognostic significance for the occurrence of a CCE, however, they showed sufficient information about survival. Indicators of TSFF over triceps and in the inguinal area, percentage of body fat did not show sufficient informativeness to predict the long-term survival of this category of patients. Poor prognosis for both survival and the onset of a CCE is associated with lower shoulder circumference, hip, TSFF over the biceps and under the shoulder blade.

Key words: chronic heart failure, prognosis, anthropometry.

\section{Адреса для листування:}

Войцеховська Катерина Віталіївна

02000, Київ, вул. Народного ополчення, 5

дУ «ННЦ « Інститут кардіології імені академіка

М.Д. Стражеска» НАМН України»,

відділ серцевої недостатності

E-mail: e voitsekhovskaya@ukr.net

Одержано 01.10.2019 